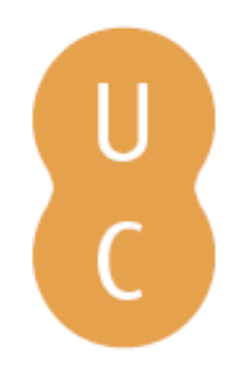

\title{
pompalina
}

\section{Radiative and convective heat exchanges between a fireman and the fire front and} wind

\author{
Autor(es): $\quad$ Conceição, Eusébio Z. E.; Lúcio, Mํㅡㄹ Manuela J. R.; Viegas, Domingos \\ X.; Viegas, Maria T.
}

Publicado por: Imprensa da Universidade de Coimbra

URL persistente:

URI:http://hdl.handle.net/10316.2/44585

DOI:

DOI:https://doi.org/10.14195/978-989-26-16-506_68

Accessed : $\quad$ 26-Apr-2023 12:31:51

A navegação consulta e descarregamento dos títulos inseridos nas Bibliotecas Digitais UC Digitalis, UC Pombalina e UC Impactum, pressupõem a aceitação plena e sem reservas dos Termos e Condições de Uso destas Bibliotecas Digitais, disponíveis em https://digitalis.uc.pt/pt-pt/termos.

Conforme exposto nos referidos Termos e Condições de Uso, o descarregamento de títulos de acesso restrito requer uma licença válida de autorização devendo o utilizador aceder ao(s) documento(s) a partir de um endereço de IP da instituição detentora da supramencionada licença.

Ao utilizador é apenas permitido o descarregamento para uso pessoal, pelo que o emprego do(s) título(s) descarregado(s) para outro fim, designadamente comercial, carece de autorização do respetivo autor ou editor da obra.

Na medida em que todas as obras da UC Digitalis se encontram protegidas pelo Código do Direito de Autor e Direitos Conexos e demais legislação aplicável, toda a cópia, parcial ou total, deste documento, nos casos em que é legalmente admitida, deverá conter ou fazer-se acompanhar por este aviso.

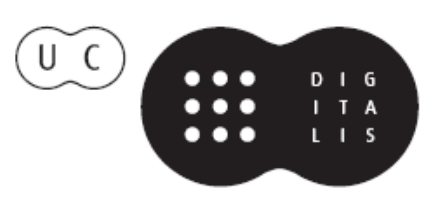




\section{ADVANCES IN}

\section{FOREST FIRE RESEARCH}

\section{8}

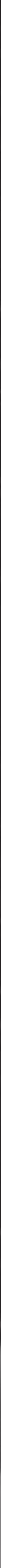




\title{
Radiative and convective heat exchanges between a fireman and the fire front and wind
}

\author{
Eusébio Z. E. Conceição ${ }^{1 *}$, Ma Manuela J. R. Lúcio ${ }^{1}$, Domingos X. Viegas ${ }^{2}$, and Maria T. Viegas ${ }^{2}$ \\ ${ }^{1}$ FCT - University of Algarve - Campus de Gambelas - 8005-139 Faro, Portugal. \\ \{econcei@ualg.pt*\} \\ ${ }^{2}$ FCT - University of Coimbra - Pinhal de Marrocos - Pólo II - 3030 Coimbra, Portugal
}

\begin{abstract}
In this work the radiative and convective heat exchanges between a fireman and the fire front and wind is made. In the radiative heat exchanges the Mean Radiant Temperature value, using the Human Thermal Response, is applied and in the convective heat exchanges the air velocity value, using the Computational Fluid Dynamics, is used.

In this work the fireman, equipped with special protective clothing, is located $5 \mathrm{~m}$ from the flame, with a height of $2 \mathrm{~m}$ and a length $10 \mathrm{~m}$, subjected to wind with air velocity of $5 \mathrm{~m} / \mathrm{s}$. The flame temperature is 1000 ${ }^{\circ} \mathrm{C}$, the air temperature is $20^{\circ} \mathrm{C}$ and the relative humidity is $50 \%$. In the paper the air velocity and the Mean Radiant Temperature around the fireman and the tissue and clothing temperature are calculated.
\end{abstract}

Keywords: Numerical Simulation, Radiative and Convective Heat Exchanges, Human Thermal Response, Mean Radiant Temperature.

\section{Introduction}

This study is a continuation of Conceição (2002), Conceição et al. (2006) and Conceição and Viegas (2010). In the previous works the radiative heat exchange was considered, using the Human Thermal Response, however in this work the convective heat exchange, using the Computational Fluid Dynamics, is also considered.

In Conceição (2002), Conceição et al. (2006) and Conceição and Viegas (2010) a numerical model, that simulates the human and clothing thermal responses, in steady-state and transient conditions, is used. This numerical model calculates not only the temperature field in the human body tissue, arterial and venous blood and clothing, but also the blood and tissue mass distribution in the human body and the water mass distribution in body skin surface and clothing. It also calculates the convective, radiative and evaporative heat exchanges, between the body and the environment and the Predicted Percentage of Dissatisfied people. This model considers the human body divided in 35 cylindrical and spherical elements, being each one sub-divided in 12 layers, which could be protected from the external environment through some clothing layers. This computational model is based on the energy balance integral equations for the human body tissue, blood and clothing as well as mass balance integral equations for the blood and transpired water in the skin surface and in the clothing. A thermoregulatory system model was implemented in order to control the human body tissue temperature.

In Conceição (2002) the present numerical model was used to study the fireman thermal sensation nearby a fire front. In the three analyzed situations, the radiant temperature, body skin and clothing temperatures and transpired sweat rate field were calculated. The more uncomfortable situation was verified when the fireman is localized in front to the fire central area and distanced $5 \mathrm{~m}$ from the flames, being the allowable exposure time, for a non-acclimatized subject with the warning criteria, of 4.5 hours. It was suggested that is important to use special protective clothing, to dispose of experimented firemen and to respect the maximum exposure time allowable. During the fire extinction was suggested that the distance between the fireman and the fire front should be the highest possible. 
It was also suggested that the fireman should avoid being located in front to the flames central area.

In Conceição et al. (2006) a numerical model, that simulates the human and clothing thermal responses, in steady-state and transient conditions, were used to study the fireman thermal sensation nearby a fire front. This numerical model was used to evaluate the thermal sensation that a fireman, equipped with special protective clothing, is subjected nearby vertical flames, with a height of $2 \mathrm{~m}$ and $10 \mathrm{~m}$ of length. In this theoretical study the fireman was placed $5 \mathrm{~m}$ distanced from the flames and localized in front to the flames central area. The body and clothing temperatures, the radiant temperature, the heat and mass fluxes fields and the comfort levels were calculated. The influence of the clothing thickness and the special protective clothing emissivity coefficient reduction, in the fireman thermal comfort sensation are analysed.

In Conceição et al. (2006) a numerical model, that simulates the human and clothing thermal responses, in steady-state and transient conditions, were used to study the fireman thermal sensation nearby a fire front. This numerical model was used to evaluate the thermal sensation that a fireman, equipped with special protective clothing, is subjected nearby vertical flames, with a height of $2 \mathrm{~m}$ and a length of $10 \mathrm{~m}$. In this theoretical study the fireman was placed $5 \mathrm{~m}$ distanced from the flames and localized in front to the flames central area. The body and clothing temperatures, the radiant temperature, the heat and mass fluxes field and the comfort levels were calculated. The influence of the clothing thickness and the special protective clothing emissivity coefficient in the fireman thermal comfort sensation was analysed. The theory used to evaluate the fireman thermal comfort is based in the extension of the PMV model. This extension, used in warm environments, combines the "static" PMV model and the adaptive model. The idea is to use the traditional PMV model, that considers the human body thermal balance, and the expectations verified in the adaptive model. It was verified that the Predicted Percentage of Dissatisfied people slightly increases when the clothing thickness increases and decreases when the special protective clothing emissivity coefficient reduces.

In Conceição et al. (2010) the radiative heat exchanges between the fire front and the firemen is made. In the radiative heat exchanges the Mean Radiant Temperature method, with correction, is applied. The Mean Radiant Temperature, the body and clothing temperature field and the Predicted Percentage of Dissatisfied people for two firemen placed perpendicularly to the fire front are calculated. In this work the radiative heat exchanges between the fire front and two firemen is evaluated. In the radiative heat exchanges the Mean Radiant Temperature method, with correction, is applied. The Mean Radiant Temperature, the skin and clothing temperature and the Predicted Percentage of Dissatisfied people are evaluated. The fireman located behind is protected to the fire front by the fireman located in front. In accordance with the obtained results the radiant protection, promoted by the fireman located in front, with a Predicted Percentage of Dissatisfied people of $25 \%$, reduces the Predicted Percentage of Dissatisfied people, that the fireman located behind is subjected, for $18.1 \%$.

\section{Physical Model}

In the Human Thermal Response and in the Computational Fluids Dynamics numerical models the human body is divided in 25 elements (see figure 1): the head, the neck, the trunk divided in three, the arms divided in four, the hands, the legs divided in four and the feet. Each element is sub-divided in 12 cylindrical or spherical layers and could be still protected of the external environment through some clothing layers. In the Human Thermal Response numerical model the elements are cylindrical or spherical, while in the Computational Fluids Dynamics numerical model the elements are boxes. 


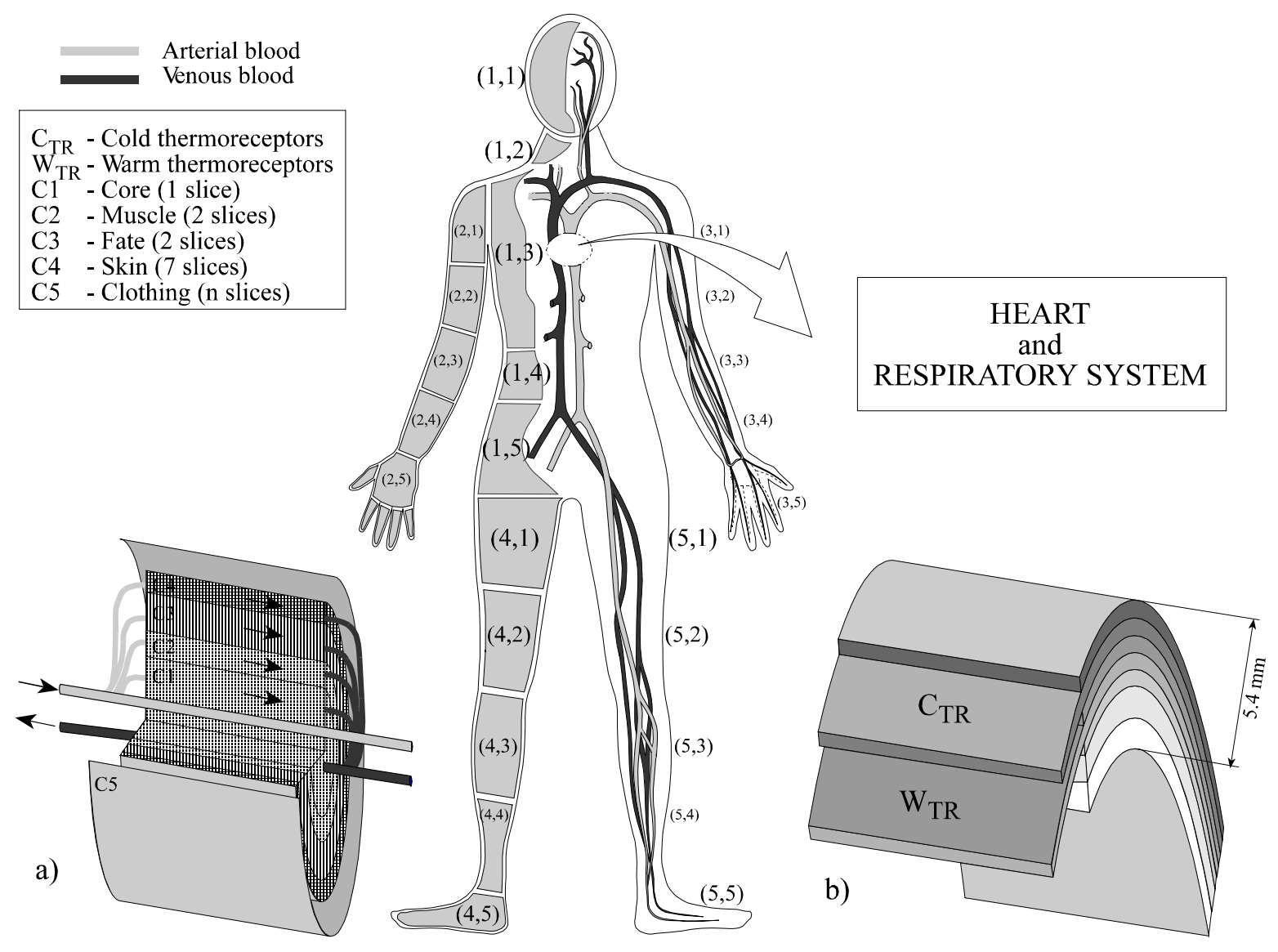

Figure 1 - Scheme of the human body divided in 35 elements. Each element divided in 12 slices and protected by clothing layers and the skin divided in 7 layers.

\section{Numerical Methodology}

This numerical model was used to evaluate the radiative and convective heat exchanges between a fireman and the fire front and wind, nearby a vertical flame, with a height of $2 \mathrm{~m}$ and $10 \mathrm{~m}$ of length, and subjected to wind boundary layer.

In this simulation the flame temperature is $1000{ }^{\circ} \mathrm{C}$ and the air mean temperature, velocity and relative humidity are, respectively, $20{ }^{\circ} \mathrm{C}, 5 \mathrm{~m} / \mathrm{s}$ and $50 \%$. In the Mean Radiant Temperature calculus the human body external surface was divided in 1256 infinitesimal areas, while the vertical fire front in 126 infinitesimal areas. In the simulation the activity level considered was $165 \mathrm{~W} / \mathrm{m}^{2}$, while the clothing level was 3 Clo.

In figure 2 the tridimentional fireman geometry used in the Human Thermal Response numerical model is presented, while in figure 3 the tridimentional localisation of the fireman in front to the flame used in the Human Thermal Response numerical model is shown. 


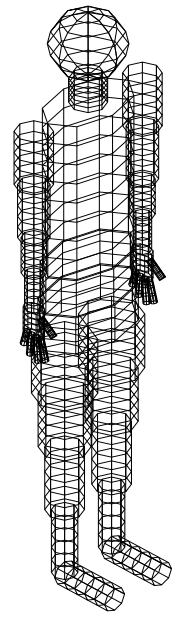

Figure 2 - Tridimentional fireman geometry used in the Human Thermal Response numerical model.

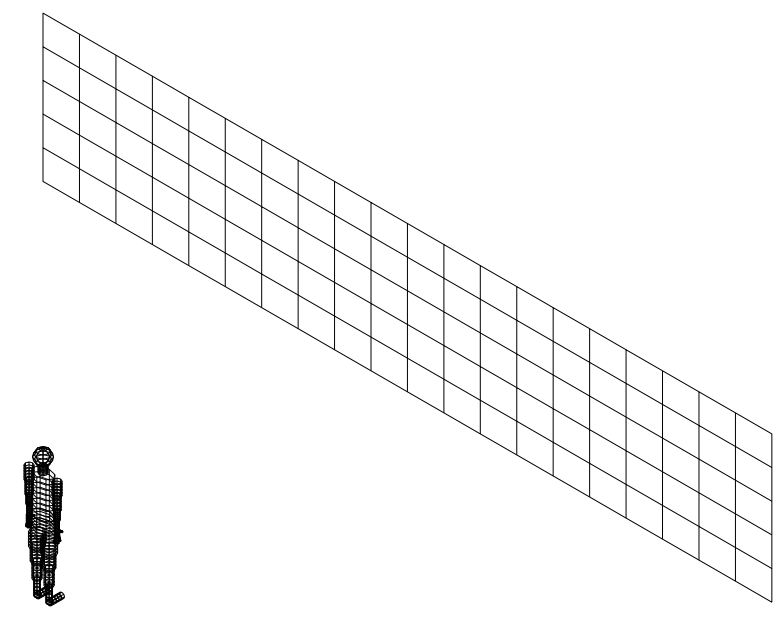

Figure 3 - Tridimentional localisation of the fireman in front to the flame used in the Human Thermal Response numerical model.

In figure 4 the tridimentional fireman geometry used in the Computational Fluids Dynamics numerical model is presented, while in figure 5 the tridimentional localisation of the fireman in front to the flame used in the Computational Fluids Dynamics numerical model is shown.

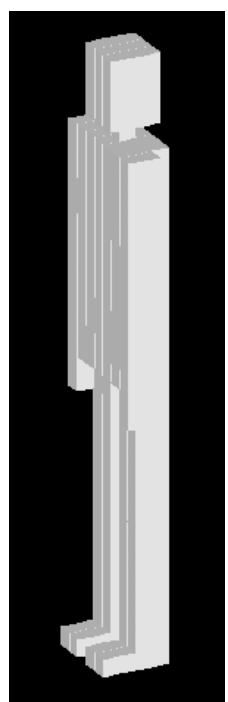

Figure 4 - Tridimentional fireman geometry used in the Computational Fluids Dynamics.

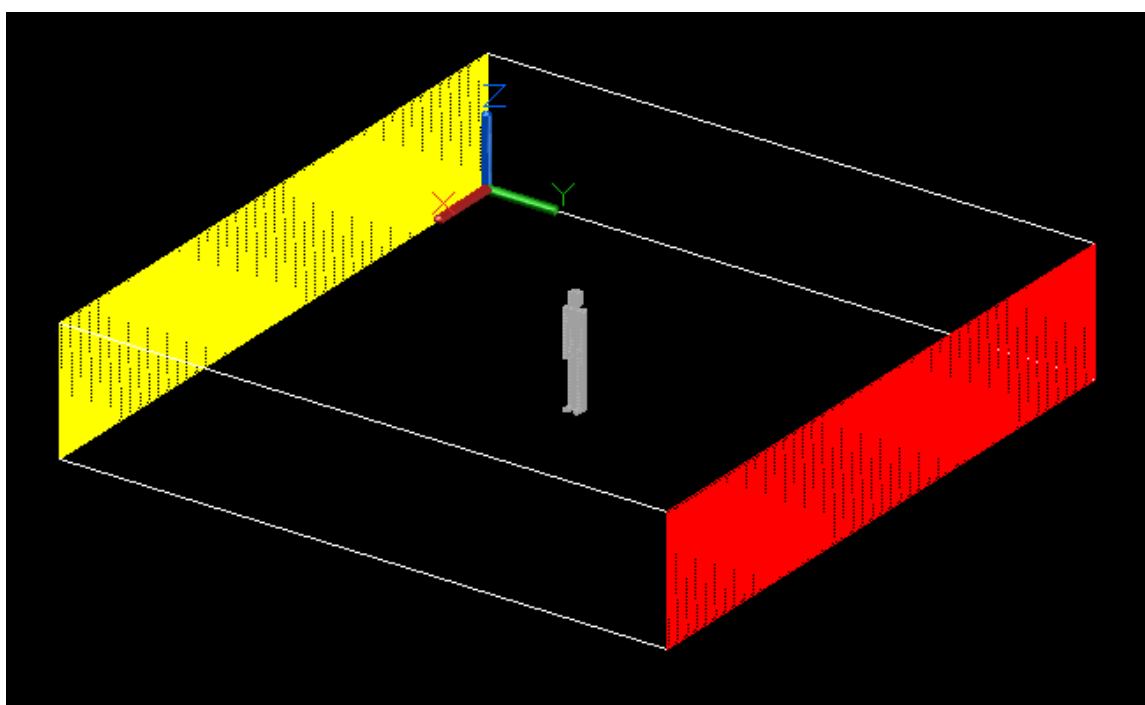

Figure 5 - Tridimentional localisation of the fireman in front to the flame used in the Computational Fluids Dynamics.

In both figures the flame front is located in front to the fireman. In figure 5 , used in the Computational Fluids Dynamics, the inlet air velocity is represented by yellow colour, in the plan XZ, while the outlet air velocity is represented by red colour, in the plan XZ.

\section{Mathematical Model}

The mathematical model is based in the Computational Fluids Dynamics and the Human Thermal Response. The two numerical models work in a coupling methodology. 


\subsection{Human Thermal Response Model}

\subsubsection{Equation System}

The human body thermal system is based on the energy and mass balance integral equations. The first one is developed for each tissue layer and for the arterial and venous blood, of each human body element. In the second one is developed, also in each element, the mass balance integral equations for the blood and for the transpired water in the skin surface.

\subsubsection{Thermoregulatory system}

The thermoregulatory system, used in the control of the human body temperature, is constituted by: heat transport from internal to external tissue, heat loss by evaporation and additional heat through shivering (see Stolwijk, 1970).

\subsubsection{Environmental variables}

The environmental variables that the model consider are the air velocity, temperature, relative humidity and Mean Radiant Temperature.

\subsubsection{Radiative Heat exchanges model}

The radiant heat exchanges by long wave phenomena are calculated, in this work, using the Mean Radiant Temperature method (Fanger, 1970), with correction. The Mean Radiant Temperature method, with correction, considers not only the heat exchanges between the human body sections and the surrounding surfaces, but also the heat exchanges between the human bodies sections of each occupant and between the human bodies sections of different occupants. The Mean Radiant Temperature method, with correction, calculates, step by step, the Mean Radiant Temperature, using the human body and surrounding surfaces temperatures, calculated in each iteration, and the precalculated view factors.

In the methodologies used in view factors determination each human body element or surrounding surfaces, with inclinations, dimensions and temperatures equal to the respective body or surrounding section, are divided in infinitesimal areas.

In the radiation by long wave phenomena calculus are also considered the shading effects that the body elements surfaces promote in each element.

\subsection{Computational Fluids Dynamics Model}

The CFD numerical model considers the three-dimensional turbulent airflows under steady-state and non-isothermal conditions. The numerical model solves the partial differential equations (using the finite volume method), namely, the mass continuity equation, moment equations (threedimensional air velocity), energy equation, turbulence kinetic energy equation and turbulence energy dissipation rate equation (using the RNG turbulence model). This numerical model is used to evaluate the airflow around the fireman (three-dimensional components of air velocity; omnidirectional air velocity, air temperature, air pressure, turbulent kinetic energy and turbulent energy dissipation rate). In the CFD numerical model each virtual fireman is based on 25 boxes elements.

\section{Results and Discussion}

In this paper the Mean Radiant Temperature and the air velocity around the fireman are calculated. In the first one is used the Human Thermal response model, while the second one is used the Computational Fluids Dynamics model.

In figure 6 is presented the Mean Radiant Temperature that the fireman are subjected in the different human body sections, while in figures 7 and 8 are presented, respectively, the air velocity that the 
fireman are subjected in a plan parallel to the airflow and the air velocity that the fireman are subjected in the different human body sections.

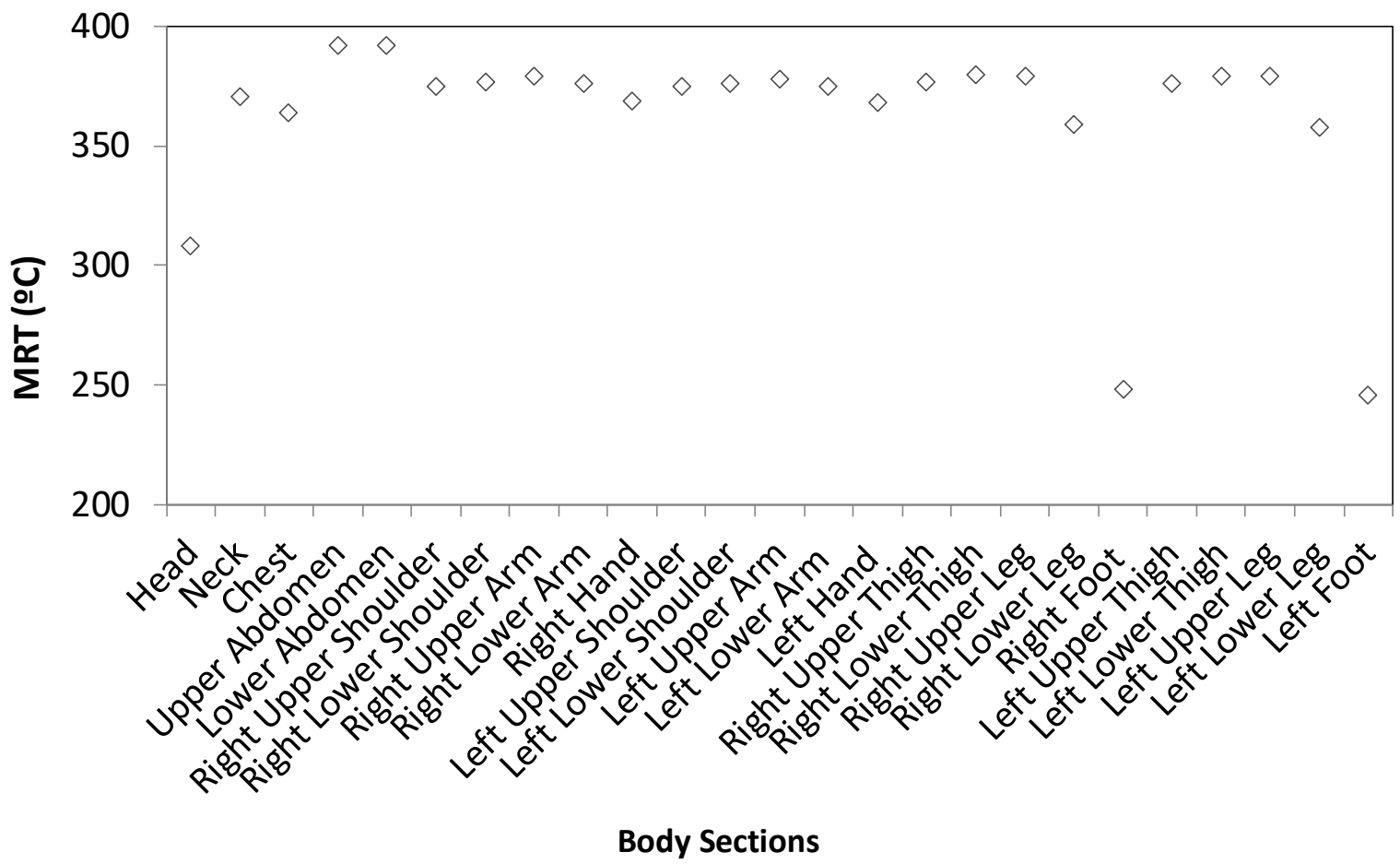

Figure 6 - Mean Radiant Temperature, MRT, that the fireman is subjected in the different human body sections.

The fire front and the surrounding environment influence the Mean Radiant Temperature. The environment influences a higher area than the fire front, while the fire front influences the higher temperature than the fire front. In accord to the obtained Mean Radiant Temperature results, is verified that:

- The Mean Radiant Temperature around the fireman is symmetrical;

- The Mean Radiant Temperature is highest in the abdomen area;

- The Mean Radiant Temperature is higher in the upper members than the lower members;

- The Mean Radiant Temperature is smallest in the feet area.

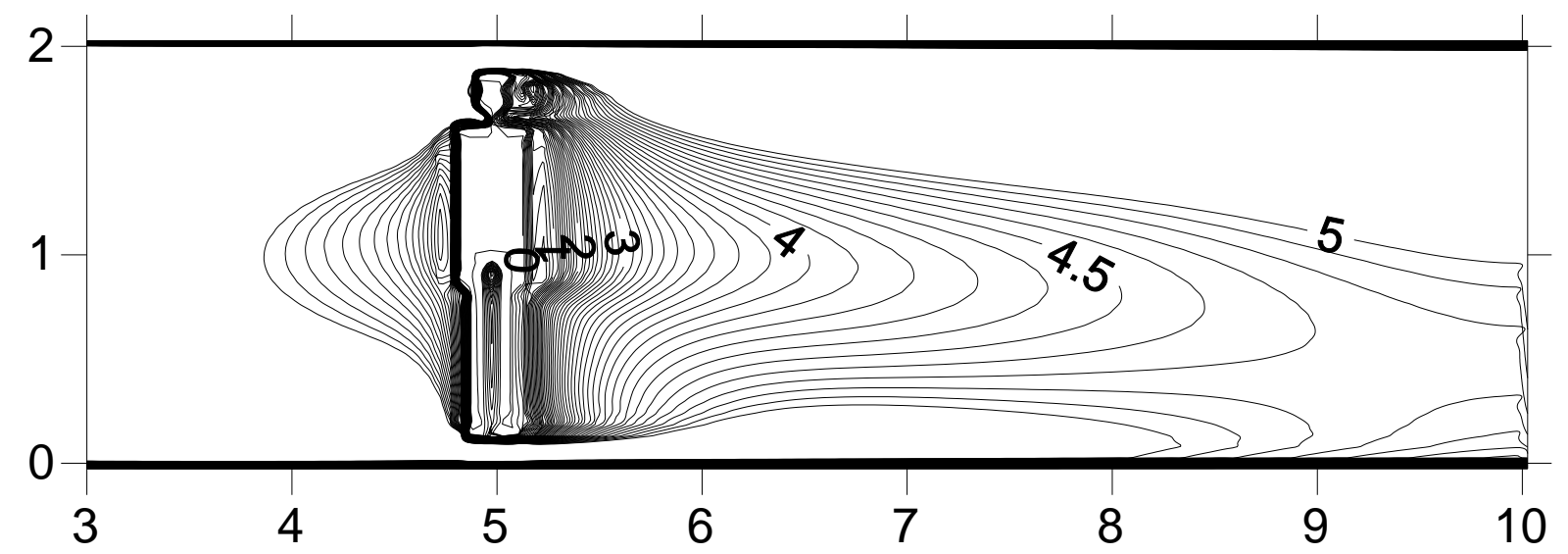

Figure 7 - Air velocity that the fireman is subjected in a plan parallel to the airflow. 


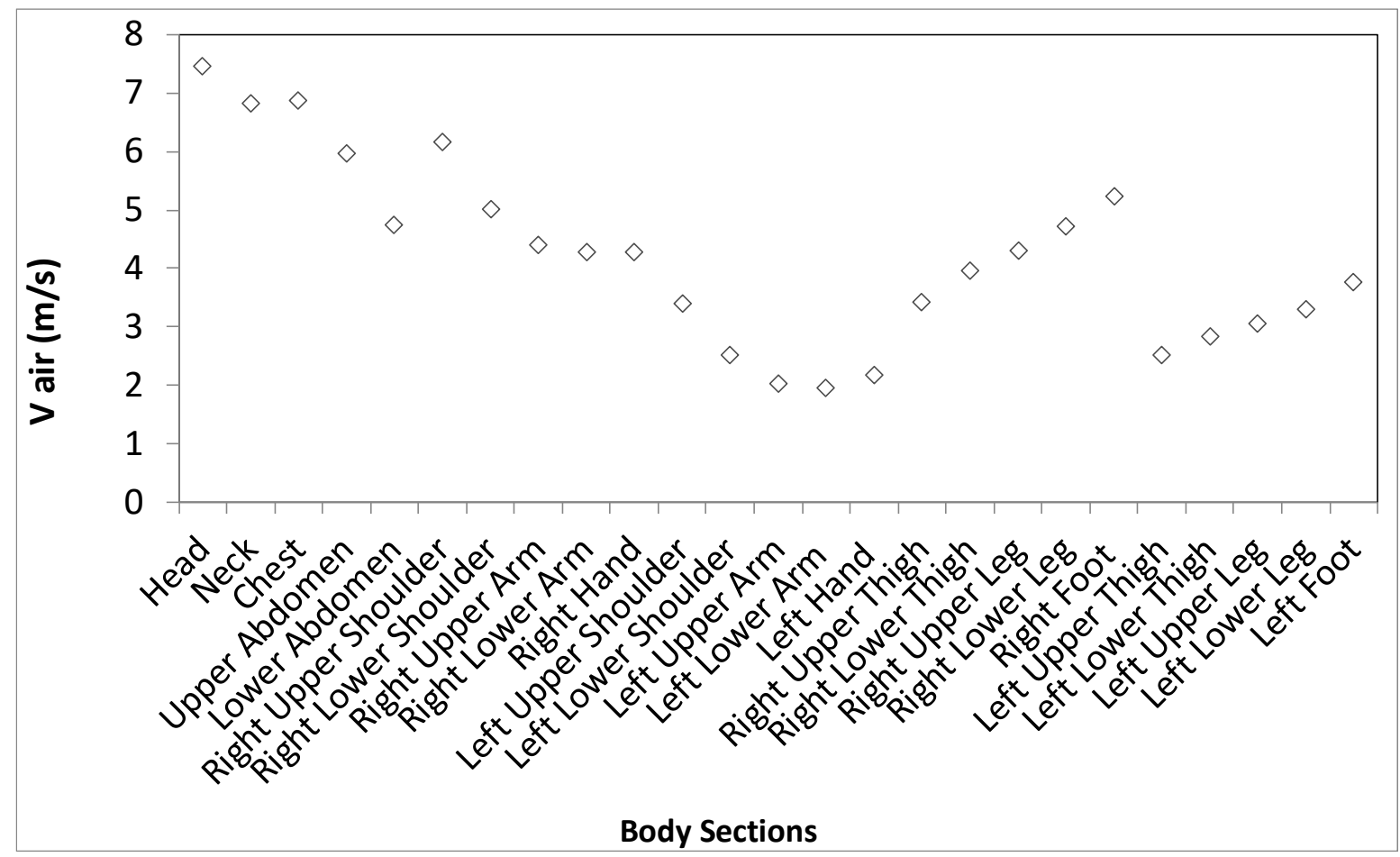

Figure 8 - Air velocity that the fireman is subjected in the different human body sections.

The airflow around the fireman guarantees a deflection in the amount area and a recirculation in downstream area. The deflection promotes a stationary area. In accord to the obtained air velocity results, is verified that:

- The air velocity is higher in the right side than in the left side;

- The air velocity is higher in the head and trunk area than in 0the members.

\section{Conclusions}

In this work the radiative and convective heat exchanges between a fireman and the fire front and wind is made. In the radiative heat exchanges the Mean Radiant Temperature is calculated, in the convective heat exchanges the air velocity is evaluated.

When the fireman is located $5 \mathrm{~m}$ from the flame, with a height of $2 \mathrm{~m}$ and a length $10 \mathrm{~m}$, the Mean Radiant Temperature is highest in the abdomen area, is smallest in the feet area and is higher in the upper members than the lower members. However, when the fireman is subjected to wind with air velocity of $5 \mathrm{~m} / \mathrm{s}$, in the right site, the air velocity is higher in the right side than in the left side and is higher in the head and trunk area than in other members.

In future work the radiative and convective heat exchanges, between a fireman and the fire front, that the fireman are subjected, will be used simultaneously in order to evaluate the human thermosphysiology and human thermal temperature distribution, for different clothing levels and activities levels.

\section{References}

Conceição E. Z. E. and Viegas D. X. 2010, Radiative Heat Exchanges Between the Fire Front and the Firemen, Proceedings of the $6^{\text {th }}$ International Conference on Forest Fire Research, Coimbra, Portugal, 15 to 18 November 2010. 
Conceição, E. Z. E. 2002. Study of Fireman Thermal Sensation Nearby a Fire Front: Evaluation of Human and Clothing Thermal Response, $4^{\text {th }}$ International Conference on Forest Fire Research, Luso, 18 to 21 November 2002.

Conceição, E. Z. E., Lúcio, Mª M. J. R. and Viegas D. X. 2006. Numerical Simulation of the Thermal Sensation of a Fireman Equipped with Special Clothing", $5^{\text {th }}$ International Conference On Forest Fire Research, Coimbra, 16 to 20 November 2006.

Fanger P.O. 1970. Thermal Comfort. Copenhagen: Danish Technical Press.

Stolwijk, J. A J. 1970. Mathematical Model of Thermoregulation", In Hardy, J. D., Gagge, A. P. and Stolwijk, J. A. J. "Physiological and Behaviour Thermoregulation", Thomas, Springfield, pp. 703721. 